\title{
Primary health care in municipalities at high risk for malaria
}

\author{
Ana Cristina Soares Ferreira ${ }^{1}$ \\ Martha Cecilia Suárez-Mutis² \\ Monica Rodrigues Campos ${ }^{3}$ \\ Claudia Garcia Serpa Osorio de Castro ${ }^{4}$
}

\begin{abstract}
This study aims to characterize aspects of Primary Health Care in the Amazon Region of Brazil, considered as the main endemic area for malaria in the country. The Ministry of Health recommends the expansion of Primary Health Care in endemic areas for malaria. A survey focusing on patients infected with malaria was conducted in 6 municipalities, in January and February 2007, to investigate specific aspects of Primary Health Care. Data was analyzed quantitatively and field records helped to give support to context and policy issues in the visited sites. Quality of access to health services and medicines, continuity of health care, system coordination and community orientation are still incipient in the visited areas. The study showed that there is little integration between Primary Health Care and malaria control in the region, which calls for development of joint strategies and for the strengthening of Primary Health Care per se, as a benefit to the population of this endemic area.
\end{abstract}

Descriptors: Primary Health Care; Malaria; Brazil.

\footnotetext{
${ }^{1}$ RN, Doctoral Student in Nursing, Escola de Enfermagem, Universidade Federal de Minas Gerais, Belo Horizonte, MG, Brazil. E-mail: anacrissofer@yahoo.com.br.

2 Physician, Ph.D. in Tropical Medicine, Laboratório de Doenças Parasitárias, Instituto Oswaldo Cruz (Fiocruz), Rio de Janeiro, RJ, Brazil. E-mail: marmutis@ioc.fiocruz.br.

${ }^{3}$ Statistician, Ph.D. in Public Health, Adjunct Professor, Escola Nacional de Saúde Pública, Instituto Oswaldo Cruz (Fiocruz), Rio de Janeiro, RJ, Brazil. E-mail: monicamp@uol.com.br.

${ }^{4}$ Pharmaceutical, Ph.D. in Child and Women's Health, Full Researcher, Escola Nacional de Saúde Pública, Instituto Oswaldo Cruz (Fiocruz), Rio de Janeiro, RJ, Brazil. E-mail: claudia.osorio@ensp.fiocruz.br.
}

Corresponding Author:

Ana Cristina Soares Ferreira

Universidade Federal de Minas Gerais. Escola de Enfermagem

Av. Prof. Alfredo Balena, 190, Sala 402

Bairro: Santa Efigênia

CEP: 30130-100, Belo Horizonte, MG, Brasil

E-mail: anacrissofer@yahoo.com.br 


\section{Atenção primária à saúde em municípios de alto risco para malária}

Neste estudo pretendeu-se caracterizar aspectos da Atenção Básica, na região da Amazônia Legal, principal área endêmica para malária, no Brasil. O Ministério da Saúde recomenda a expansão da Atenção Básica nas áreas malarígenas. Foi realizado inquérito transversal, aplicado aos portadores de malária, em 6 municípios, durante os meses de janeiro e fevereiro de 2007. Os dados coletados foram tabulados e analisados, utilizandose técnicas quantitativas. Registros de campo auxiliaram na composição das impressões do contexto dessas políticas nos locais pesquisados. A qualidade do acesso a consultas e medicamentos, o vínculo com os profissionais e com as Unidades Básicas de Saúde, o sistema de referência e contrarreferência, e a abordagem familiar e comunitária da saúde pelos profissionais, nos municípios do estudo, ainda são deficientes nesse nível de atenção. Há baixa integração entre o Programa Nacional de Controle de Malária e a Atenção Básica, de modo geral.

Descritores: Atenção Primária à Saúde; Malária; Brasil.

\section{Atención primaria a la salud en municipios de alto riesgo para malaria}

Este estudio pretende caracterizar aspectos de la Atención Básica en la región de la Amazonia Legal, principal área endémica para malaria en Brasil. El Ministerio de la Salud recomienda la expansión de la Atención Básica en las áreas afectada por la malaria. Fue realizado una encuesta transversal aplicada a los portadores de malaria en 6 municipios, durante los meses de enero y febrero de 2007. Los datos recolectados fueron tabulados y analizados utilizando técnicas cuantitativas. Registros de campo auxiliaron en la composición de las impresiones del contexto de estas políticas en los locales investigados. La calidad del acceso a consultas y medicamentos, el vínculo con los profesionales y con las Unidades Básicas de Salud, el sistema de referencia y contra-referencia y el abordaje familiar y comunitario de la salud por los profesionales en los municipios del estudio también son deficientes en este nivel de atención. Existe una baja integración entre el Programa Nacional de Control de Malaria y la Atención Básica de un modo general.

Descriptores: Atención Primaria en Salud; Malaria; Brasil.

\section{Introduction}

Primary Health Care (PHC) was approved in 1978, with the Declaration of Alma-Ata, as the main strategy for reaching the goal of "Health for all in the year 2000"(1). In Brazil, since 1994, the Health Ministry has been encouraging the expansion of $\mathrm{PHC}$, also known as Basic Care, through the Family Health Strategy $(E S F)^{(2)}$. According to the recommendations of the Health Ministry's Health Care Surveillance Office, one of the most important actions for improving malaria control policies is expanding the PHC network in the Amazon region(3). In the attempt to establish a regional policy for PHC in this region, in the period from 2003 to 2005, greater funding was given to the ESF and to control of endemic situations, but this favorable treatment was not extended to all programs and there is still great institutional need in municipalities of the Amazon ${ }^{(4)}$.

The Brazilian Amazon includes the states of Acre, Amapá, Amazonas, Pará, Rondônia, Roraima and part of Maranhão, Mato Grosso and Tocantins. This region represents approximately $60 \%$ of the Brazilian territory, encompasses the Amazon forest and has developed into one of the country's last agricultural frontiers, with multiple settlements, resulting in deforestation and burnings. Logging, mining and extraction without adequate environmental management aggravate the region's susceptibility to social conflict and sanitary 
risks, including malaria(5). The Amazon is an endemic region for malaria in Brazil, concentrating around 99.5\% of the cases in the country.

The epidemiological scenario for malaria is heterogeneous and annual data fluctuate. According to the Brazilian Malaria Control Program (PNCM), there was a gradual reduction in the number of malaria cases between 1999 and 2002. Beginning in 2003, there was an increase, reaching 603,532 cases in 2005. In 2006, 540,047 cases were notified and the numbers fell again in 2008 , when $315,716^{(6)}$ cases were notified.

The PNCM advocates that malaria be diagnosed through examination of thick-smear, in order to identify the type of plasmodium(5). This activity is mainly performed by agents of the Epidemiological Surveillance Office and the Endemic Management (AE) at the Basic Health Care Units (UBS) and, when necessary, in households. Ordinance No. 44/GM, of January $3 r d, 2002^{(7)}$, states the need to include epidemiology and disease control actions in PHC management, emphasizing the importance of health education relative to basic knowledge in malaria and dengue prevention and control. This ordinance also reaffirms the importance of Community Health Agents (ACS) in the prevention and control of these diseases and indicates the need to incorporate surveillance, prevention and control actions in Community Health Agent Programs (PACS) and by the $\mathrm{ESF}^{(7)}$ activities.

However, low social protection in the region, including a lack of basic health care and effective measures for integrated malaria control, contribute to the occurrence of deaths, suffering and social loss(5).

This article aims to describe and discuss specific $\mathrm{PHC}$ characteristics and some of its dimensions in municipalities at high malaria risk in the Brazilian Amazon. Few studies have been developed to clarify how PHC functions in areas where malaria is endemic. References were found about related but different themes: a current reference about how to develop nursing practices in community health, in the context of vulnerable regions like the Amazon ${ }^{(8)}$; and two older references, one on the integration of Chagas disease control in the PHC network ${ }^{(9)}$ and the other on the successful eradication of malaria in Costa Rica through the collaboration of $\mathrm{PHC}$ services ${ }^{(10)}$.

\section{Methods}

The study is nested in the Mafalda Project(11). This project assessed pharmaceutical services in the treatment of non-complicated malaria (organization of services, prescribing, dispensing and adherence), with funding from the National Council for Scientific and Technological Develoment (CNPq), counting with teams of trained researchers for visits to the Amazon Region municipalities. With the study's main focus being pharmaceutical services, there were certain limitations in the PHC branch, such as the researchers' approach of patients and the impossibility of covering some $\mathrm{PHC}$ dimensions, for example, comprehensive care and professional training. The user sample was not random for the PHC search, because the users who participated in the survey were malaria patients.

We tried to incorporate PHC aspects proposed by Starfield ${ }^{(12)}$ and adapted to Brazilian reality by Almeida e Macinko(13). We used the access to first contact, coordination, continuity of care and family and community orientation dimensions. A cross-sectional study was conducted, from January to February 2007, in UBS in the municipalities of Manaus and Presidente Figueiredo, in the state of Amazonas; Porto Velho and Ariquemes, in the state of Rondônia; and Cruzeiro do Sul and Rodrigues Alves, in the state of Acre. These represented small, medium and large-scale municipalities among the highest annual parasite incidences (API) for malaria(6).

The eligibility criteria included UBS that notified malaria in urban areas and that were less than $50 \mathrm{~km}$ from urban centers, a total of six units. More distant communities were excluded for logistical reasons. The selected units were not reference centers for treating serious and complicated malaria, but health care units for daily PHC, including suspected malaria cases. The interviews were applied to patients aged over 18, who went to the UBS with a malaria complaint. Pregnant women were excluded, as they were referred to reference centers for malaria treatment. The patients were approached when the thick blood smear test for malaria diagnosis was performed. After the pilot study, it was observed that this was the moment when the approach would be most successful. It would also offer an opportunity to observe the prescribing and dispensing of antimalarials that took place concomitantly with data collection. The intended sample was 300 patients and 271 accepted participation. The data collection instruments were built on the basis of the aforementioned dimensions ${ }^{(13)}$. The instrument contained 24 questions and was assessed via a pilot study, performed in the municipality of Tucuruí, in the state of Pará. The field researchers included physicians, nurses and pharmacists, all previously trained. For data 
analysis, the statistical package SPSS 8.0. was used and the results will be presented according to each PHC dimension researched.

In order to strengthen the analysis, we used impressions of the municipalities' context, recorded during the daily field visits, to illustrate tangent aspects of $\mathrm{PHC}$ in the region. The study followed the ethical norms for research with human beings (Resolution CNS 196/96). UBS managers were asked for access authorization. Patients were interviewed after acknowledging and giving informed consent. Approval for the study was obtained from the Research Ethics Committee of the National Public Health School/Fiocruz, under number 91/06 CAAE: 0086.0.031.000-06.

\section{Results and Discussion}

\section{Context}

Brazilian Malaria Control Program and Primary Health Care

The PNCM was an important presence in the field, especially through the actions of the $A E$, who performed thick blood smear collection for malaria diagnosis, dispensed medication and actively sought new cases. It was seen that referral for thick blood smear collection in case of fever is protocol for the establishment of differential diagnosis in the municipalities. There were cases in which the ACS and the AE were working in the same region. The $A E$ were supported by the presence of a coordinator, called endemics manager, and a microscopist. These technicians, normally divided into patient care, vector control and environmental control, often performed their work at a UBS, where other PHC activities were carried out.

However, integration between these activities was not observed. The PNCM services generally worked as attachments to the UBS and the PHC professionals did not treat malaria patients. The AE performed consultations and prescribed antimalarials and only referred more serious or group-risk cases, such as children and pregnant women, to medical or nursing consultation at malaria reference centers. The PNCM and PHC actions generally occurred in parallel, with no communication between professionals. This is a curious situation, since the decentralized management authority should coordinate both PHC and malaria control actions ${ }^{(14)}$.

According to the field records, the action of the $\mathrm{PHC}$ physician or nurse in malaria care in the municipalities was very restricted or inexistent. The responsibility for diagnosis and treatment lay with the $A E$ and microscopists.

\section{Primary Health Care Dimensions}

Access to PHC services is related to patients' ability to access a health care unit, their ease in obtaining a consultation and the unit's availability and utility as the individual's first contact for solving health problems ${ }^{(12)}$. We know that one of the main ESF results has been improved basic health care services for the population ${ }^{(15)}$.

Primary Health Care in the region took a variety of formats. There were units with ESF teams, traditional UBS and PHC services in clinics and general hospitals. Apart from these, primary health services were performed at the Special Sanitary Indigenous Districts (DSEI). ESF teams are mainly present in rural areas, which can be explained by the original conception of the Family Health Program (PSF), where the implementation focus was on higher-risk and lower-access areas ${ }^{(2)}$.

In the field reports, PHC managers told us that care occurs in places of difficult access, such as the countryside, riverside communities or peripheral urban areas. In the latter, there is high demand for night care, especially in hospitals.

Some municipalities had ESF teams covering various communities in rural areas. Other teams traveled to rural areas daily and returned to the municipality headquarters at the end of the day. Some teams visited the communities in their coverage area with varying frequency, in compliance with a previously set schedule. In cases where there was support from ambulances and roads, patients in rural households were picked up. Some municipalities counted with seasonal health care initiatives for the rural or riverside areas, via group efforts to care for isolated populations during floods. The high demand for care caused work overload for these teams.

In very distant communities, the ESF presence, in the form of ACS activity, was limited, even for malaria care. It was recorded that patients from these communities travelled to UBS in municipalities other than their own for medical consultations or malaria care, as they were closest.

In terms of the proportion of patients who use the UBS as access to first contact, $39.9 \%$ of the interviewees answered that they go to a Primary Health Care Unit when they get sick. The public hospital was the second most frequent "entrance", with $24.3 \%$ of answers; $23.5 \%$ answered that they are treated at home; and $2.6 \%$ of respondents go to a pharmacy when they get 
sick. No patients pay for private health care out of their own pockets and only $1.1 \%$ of the interviewed population sought private health care insurance, which is not strange in the Amazon region, where $46.2 \%$ of people are considered poor, a higher proportion than the national average of $33.4 \%{ }^{(16)}$.

We assessed whether the individuals were prescribed medication to care for their health problems (other than malaria); $82.6 \%$ of the interviewees received a prescription, but $62.4 \%$ could not get all the medications at the UBS. In view of the profile of the population being served, it is possible that the patients did not have access to the medication that was not available at the UBS. If adequately implemented, PHC could make a big difference in aid and medication access for this population, reinforcing the UBS's role as access to first contact.

The rural and riverside populations seemed to be the most vulnerable groups, as they face the greatest access barriers: geographical, financial and information barriers. This population is greatly affected by malaria. A disconnection between malaria care and PHC, contradicting the Ministry of Health's(7) assumptions, causes duplication of care efforts and compromises the system's comprehensiveness, making it less likely for $\mathrm{PHC}$ to be provided in a rational manner.

The continuity of care involves the existence of a physician or a team and the use of a certain health care service by patients, without being limited to specific diseases $^{(12)}$. Adequate recording of the patient's clinical history and scheduling of a return visit also help to establish the continuity of care ${ }^{(12)}$.

A study in the municipality of Ribeirão Preto, in the state of São Paulo, assessed the establishment of the continuity of care in tuberculosis control services. Performance was considered favorable in this aspect, providing better adherence to the treatment. However, the best results were found in programs where fewer people received care, demonstrating that excess demand complicates communication and the patienthealth care professional relationship and, consequently, the continuity of care(17).

Out of the total number of interviewees who received medical consultation, $34.4 \%$ reported that they were advised to go back for a scheduled consultation. Approximately $65 \%$ of the interviewees reported not being seen by the same physician or even the same nurse when they sought care at the UBS. There were reports of the physician's full-time absence at the UBS. In any case, the patient who sought care hoped to continue his/her treatment with the same physician or nurse, being disappointed when this failed to occur. The ideal situation is for patients to have a longlasting interpersonal relationship with the health care professionals who take care of them(12).

According to field records, professional turnover is high, especially for physicians; some nurses had to perform as proxy physicians in municipalities where these professionals were not present. Difficult in access to municipalities, precarious living conditions, lack of continuous employment by municipalities and lack of minimum resources for work were considered some of the factors generating the high turnover of professionals. Lowering the turnover of health care professionals involved in PHC activities in the Amazon region is another of the goals of the $\mathrm{PNCM}^{(3)}$, which recognizes the importance of the close relationship between malaria health care professionals and $\mathrm{PHC}$.

When interviewed, $44.1 \%$ of patients reported a lack or insufficiency of time needed to answer their questions during the consultation. The Health Ministry's Ordinance No. 648/2006(2) determines that the actions of ESF and oral health professionals must include listening to users' needs.

Information was collected about the perceived quality of the contact between patients and health professionals. The assessments that the contact was "very good" or "good", jointly, corresponded to $64 \%$ of the answers. Contact classified as "regular" and "bad" made up $36 \%$ of the responses.

Interrupted care can also hamper continuity. In the rural zones of some municipalities, care is only performed by ESF on weekends, according to the field reports. This situation may also contribute to a lack of communication between health care team members, especially between the ACS and other health care professionals who live outside the rural area. The team's absence also hinders supervision, monitoring and continued education of the ACS, according to the managers, and goes against the Ministry of Health' $s^{(2)}$ directives on health worker training.

In Brazil, the literature points to failures in coordination between PHC services and more complex services $^{(18)}$.

With respect to the coordination system adopted in the municipalities visited, only $67 \%$ of patients reported that the professionals took notes in their records during the consultation. Out of the patients referred to a specialist, $43.8 \%$ received a medical report from the $\mathrm{PHC}$ professionals and $56.3 \%$ did in fact go to the specialist. 
Out of these, only $32 \%$ received written information for a return consultation with the UBS physician. From all the people referred for a consultation with a specialist, only $18.8 \%$ went back to the UBS at the end of the process.

The percentage of referrals reported by the study's patients, $17.4 \%$, is close to the Health Ministry's determinations, which estimate that around $15 \%$ of complaints made in $\mathrm{PHC}$ should be referred to care at secondary and tertiary level. The problem detected was in relation to the referred patients, who did not have consultations at this other care level, which suggests the presence of access barriers to the secondary and tertiary care levels and a repressed demand for $\mathrm{PHC}^{(18)}$.

From the community point of view, Starfield(12) considers the influence of environmental, social and behavioral factors to be important in the causes and development of diseases and suggests that professionals tackle this theme for more effective care.

A study performed in São José do Rio Preto, in the state of São Paulo, assessed, the performance of health care services in tuberculosis control according to patients' perceptions, in the family focus and community orientation dimensions. In the family focus dimension, it was shown that health care professionals are more concerned with patients' signs and symptoms than with life circumstances that can compromise family health. The community orientation dimension, which includes activities that depend on patients, such as seeking information in posters and other educational materials, scored high marks. However, the scores were not satisfactory when it came to responsibility for actively seeking cases for sputum collection and encouraging the community to discuss health problems related to tuberculosis(19).

In the municipalities, $71 \%$ of the interviewees reported that health care professionals do not ask about their living conditions during the consultation. But around $54 \%$ of the patients believed the professionals know about the community's main problems. Approximately $77 \%$ of the interviewees admitted that the UBS professionals do not work with other organizations in the community. Half the patients interviewed reported receiving household visits at the time.

After the changes to the PHC funding criteria and the ACS's coverage parameters, when each agent was allowed to monitor fewer people, there was an increase of 7,435 new ACS in the region(20). This expansion may have generated positive impacts, but a contingent of the population is still not being covered, suggesting the need for a greater increase in the number of teams and professionals to monitor the families. The ACS's presence is not enough, because he or she must be trained, through continued education activities performed by ESF members, such as physicians and nurses, by the Municipal and State offices, when applicable, and by PNCM professionals. Besides training, the ACS need constant supervision and coordination from the ESF physician and nurse, and this must be integrated to the endemics managers' supervision activities.

In this dimension, the question of information about the existence of and participation in malariaprevention activities is a cause for concern. In relation to educational activities about malaria prevention, 69\% of the patients were not aware of any practice of this kind in the community and $78 \%$ of the interviewees had never participated in any educational activity on malaria prevention. However, when it came to actions developed by professionals during household visits, $64.2 \%$ answered that the professional gave them guidance about disease prevention. As seen, prevention actions are being performed in some way during household visits or by certain ACS or AE.

Because the interviewees are malaria patients and inhabitants of endemic areas, we may observe that there are flaws related to preventive measures and effective social protection actions. The study showed that health care professionals involved in PHC, especially those in ESF, are having trouble approaching risk groups in the communities, during household visits or in integrating with other community institutions.

Responsibility for the low community and family orientation cannot be solely attributed to the health care professionals but also to the managers, who play a fundamental role in encouraging and controlling this function. Besides, community organization, such as residents' associations and participation in Municipal Health Councils, among others, could support and regulate community health actions, exercising social control(21).

Although $50 \%$ of the population receives household visits, it is necessary to increase both the ESF coverage and the PNCM actions in the region. Connecting actions, both by increasing the ACS and by joint actions with $A E$, would favor family monitoring and epidemiological surveillance.

The gradual expansion of the ESF teams and the number of $\mathrm{ACS}^{(20)}$, which is currently occurring in the region, can be seen as a positive factor. Other factors that have been favoring PHC integration and the fight against malaria related to the PNCM, include: rapid diagnosis 
via thick blood smear, regular supply of antimalarials and the efforts of the health teams towards treatment, prevention and control of malaria.

\section{Conclusions}

In relation to the characteristics of $\mathrm{PHC}$ observed in the malaria-ridden municipalities of the Brazilian Amazon, the following can be highlighted: (i) there is a lack of integration between the Brazilian Primary Health Care Policy and the national Malaria Control Policy; (ii) most physicians, nurses and other professionals involved in $\mathrm{PHC}$ are distant from the treatment and prevention of malaria; (iii) there are deficiencies in access, continuity, coordination and family and community orientation dimensions of PHC in municipalities in this region.

The performance of the PHC dimensions shows that there is ample room for improvement at this level of care. In addition, the region would benefit from a reassessment of its health policies, in relation to the concession of incentives for maintaining $\mathrm{PHC}$ professionals, the supervision of the elements needed to integrate PHC and malaria control, the assessment of PHC managers' and professionals' actions and the training and coordination of joint actions between the various types of health care agents active in the region.

For the field of nursing, the study helps to reveal the context in which these professionals are developing their work in the Amazon region: dichotomies between health policies, situations where the physicians is sometimes absent and a lack of adequate structure, damaging the efficiency of health care actions and endangering these professionals' work expectations.

Brazil is facing challenges in relation to $\mathrm{PHC}$ expansion and training and the consolidation of the ESF. However, health care policies for the endemic malaria region in Brazil must be planned, including attention to its peculiarities: a region with a high professional turnover, difficult geographical conditions and a population with little schooling and a low socio-economic level. For all of these reasons, the region requires effective social protection policies, among which strategies for training and strengthening the integration between Primary Health Care and the Brazilian Malaria Control Program.

\section{References}

1. Organização Mundial de Saúde. Saúde para todos no ano 2000. Genebra: OMS; 1978.
2. Portaria n. 648 de 28 de março de 2006 (BR). Aprova a Política Nacional de Atenção Básica, estabelecendo a revisão de diretrizes e normas para a organização da Atenção Básica para o Programa Saúde da Família e o Programa de Agentes Comunitários de Saúde. Diário Oficial da União. Brasília; 2006.

3. Ministério da Saúde (BR). Secretaria de Vigilância em Saúde. Situação Epidemiológica da Malária no Brasil. [acesso 27 set 2010]. Disponível em:

http://portal.saude.gov.br/portal/arquivos/pdf/folder_ malaria_2007_web.pdf

4. Viana ALA, Machado CV, Baptista TWF, Lima LD, Mendonça MHM, Heimann LS et al. Sistema de saúde universal e território: desafios de uma política regional para a Amazônia Legal. Cad Saúde Pública. 2007;23:(supl 2):117-31.

5. Ministério da Saúde (BR). Secretaria de Vigilância em Saúde. Programa Nacional de Prevenção e Controle da Malária. Brasília: Ministério da Saúde; 2003. 132 p.

6. Ministério da Saúde (BR). Secretaria de Vigilância em Saúde. DATASUS - Sistema de Informação de Vigilância Epidemiológica. [acesso 27 set 2010]. Disponível em: http://dw.saude.gov.br/portal/page/portal/sivep_ malaria?Ano_n=2008

7. Portaria n. 44 de 03 de janeiro de 2002 (BR). Estabelece as atribuições do agente comunitário de saúde na prevenção e controle da malária e da dengue. Diário Oficial da União [periódico na Internet]. [acesso 6 jan 2007] Disponível em:

http://www.funasa.gov.br/web\%20Funasa/Legis/pdfs/ portarias_m/pm_44_2002.pdf

8. Laperrière H. Práticas de enfermagem em saúde coletiva nos contextos de pobreza, incerteza e imprevisibilidade: uma sistematização de experiências pessoais na Amazônia. Rev. Latino-Am. Enfermagem. [periódico na Internet]. set-out 2007;15(no esp):7218. [acesso 13 dez 2010]. Disponível em: http://www. scielo.br/scielo.php?script $=$ sci_arttext\&pid $=$ S0104$11692007000700002 \&$ Ing $=$ en\&nrm=iso. doi: $10.1590 /$ S0104-11692007000700002.

9. Dias JCP. Integração das Ações de Controle das Endemias com Rede Básica de Saúde: Doença de Chagas. Rev Bras Malariol Doenças Trop. 1986;38:7785.

10. Garcez J. Colaboraçäo entre os serviços primários de saúde e a campanha de erradicaçäo da malária de Costa Rica. Rev Bras Malariol Doenças Trop. 1985;37(supl):167-70. 
11. Osorio-de-Castro CGS, Chaves GC, Ruiz AM, Miranda ES, Campos MR, Mutis MCS, et al. A proposal for an evaluation model of pharmaceutical services for malaria. Cad Saúde Pública. 2009;25:2075-82.

12. Starfield B. Atenção primária: equilíbrio entre necessidades de saúde, serviços e tecnologia. Brasília (DF): UNESCO; 2002.

13. Almeida C, Macinko J. Validação de uma metodologia de avaliação rápida das características organizacionais e do desempenho dos serviços de atenção básica do Sistema Único de Saúde (SUS) em nível local. Brasília (DF): OPAS; 2006.

14. Ladislau JLB, Leal MC, Tauil PL. Avaliação do Plano de Intensificação das Ações de Controle da Malária na região da Amazônia Legal, Brasil, no contexto da descentralização. Epidemiol Serviços Saúde. 2006;15(2):9-20.

15. Kantorski LP, Jardim VMR; Coimbra VCC, Oliveira MM, Heck, RM. A Integralidade da atenção à saúde na perspectiva da gestão no município. Texto Contexto Enferm. 2006;15(3):434-41.

16. Ministério da Saúde (BR). Datasus [Internet]. Indicadores do Pacto de Atenção Básica. [acesso 10 jun 2007] Disponível em:

http://tabnet.datasus.gov.br/cgi/deftohtm.exe?siab/ pacto2006/pacbr.def

17. Brunello MEF, Cerqueira DF, Pinto IC, Arcênio RA, Gonzales RIC, Villa TCS, et al. Vínculo doente-profissional de saúde na atenção a pacientes com tuberculose. Acta Paul Enferm. 2009;22(2):176-82.

18. Nascimento MS, Nascimento MAA. Prática da enfermeira no Programa de Saúde da Família: a interface da vigilância da saúde versus as ações programáticas em saúde. Ci Saúde Colet. 2005;10(2):333-45.

19. Oliveira SAC, Ruffino NA, Villa TCS, Vendramini SHF, Andrade RLP, Scatena LM. Serviços de saúde no controle da tuberculose: enfoque na família e orientação para a comunidade. Rev. Latino-Am. Enfermagem. [periódico na Internet] 17(3):361-7 jun 2009 [acesso 9 ago 2011 ]; Disponível em: http://www.scielo.br/ scielo.php?script=sci_arttext\&pid=S01041169200900 0300013\&lng=en. http://dx.doi.org/10.1590/S010411692009000300012

20. Solla JJS P, Reis AAC, Soter APM, Fernandes AS, Palma JJL. Mudanças recentes no financiamento federal do Sistema Único de Saúde: atenção básica à saúde. Rev Bras Saúde Materno Infantil. 2007;7(4):495-502.
21. Lei n. 8080 de 19 de setembro de 1990 (BR). Dispõe sobre as condições para a promoção, proteção e recuperação da saúde, a organização e o funcionamento dos serviços correspondentes, e dá outras providências. Diário Oficial da União, 19 set 1990. Brasília; 1990.
Received: Mar. 14 2011 Accepted: Oct. $11^{\text {th }} 2011$ 